\title{
Prediction of the formation of biogenic non-extractable residues during degradation of environmental chemicals from biomass yields
}

Trapp, Stefan; Brock, Andreas Libonati; Nowak, Karolina Malgorzata; Kästner, Matthias

\section{Published in:}

Environmental Science and Technology

Link to article, DOI:

10.1021/acs.est.7b04275

Publication date:

2018

Document Version

Peer reviewed version

Link back to DTU Orbit

Citation (APA):

Trapp, S., Brock, A. L., Nowak, K. M., \& Kästner, M. (2018). Prediction of the formation of biogenic nonextractable residues during degradation of environmental chemicals from biomass yields. Environmental Science and Technology, 52(2), 663-672. https://doi.org/10.1021/acs.est.7b04275

\section{General rights}

Copyright and moral rights for the publications made accessible in the public portal are retained by the authors and/or other copyright owners and it is a condition of accessing publications that users recognise and abide by the legal requirements associated with these rights.

- Users may download and print one copy of any publication from the public portal for the purpose of private study or research.

- You may not further distribute the material or use it for any profit-making activity or commercial gain

- You may freely distribute the URL identifying the publication in the public portal 


\title{
Article
}

Subscriber access provided by DTU Library

\section{Prediction of the formation of biogenic non-extractable residues during degradation of environmental chemicals from biomass yields}

\author{
Stefan Trapp, Andreas Libonati Brock, Karolina Malgorzata Nowak, and Matthias Kästner
}

Environ. Sci. Technol., Just Accepted Manuscript • DOI: 10.1021/acs.est.7b04275 • Publication Date (Web): 07 Dec 2017

Downloaded from http://pubs.acs.org on December 13, 2017

\section{Just Accepted}

"Just Accepted" manuscripts have been peer-reviewed and accepted for publication. They are posted online prior to technical editing, formatting for publication and author proofing. The American Chemical Society provides "Just Accepted" as a free service to the research community to expedite the dissemination of scientific material as soon as possible after acceptance. "Just Accepted" manuscripts appear in full in PDF format accompanied by an HTML abstract. "Just Accepted" manuscripts have been fully peer reviewed, but should not be considered the official version of record. They are accessible to all readers and citable by the Digital Object Identifier (DOI®). "Just Accepted" is an optional service offered to authors. Therefore, the "Just Accepted" Web site may not include all articles that will be published in the journal. After a manuscript is technically edited and formatted, it will be removed from the "Just Accepted" Web site and published as an ASAP article. Note that technical editing may introduce minor changes to the manuscript text and/or graphics which could affect content, and all legal disclaimers and ethical guidelines that apply to the journal pertain. ACS cannot be held responsible for errors or consequences arising from the use of information contained in these "Just Accepted" manuscripts. 
1 Prediction of the formation of biogenic non-extractable residues during degradation of

2 environmental chemicals from biomass yields

3 Stefan Trapp ${ }^{a}$, Andreas Libonati Brock ${ }^{a}$, Karolina Nowak ${ }^{\mathrm{b}}$, Matthias Kästner ${ }^{\mathrm{b},{ }^{*}}$

4

5 a Department of Environmental Engineering, Technical University of Denmark, Bygningstorvet

6 bd. 115, DK-2800 Kgs. Lyngby, Denmark.

$7 \quad{ }^{\mathrm{b}}$ Helmholtz-Centre for Environmental Research - UFZ, Department of Environmental

8 Biotechnology, Permoserstr. 15, 04318 Leipzig, Germany.

$9 \quad$ * Corresponding author: Matthias Kästner; phone: 0049-341-235-1235; fax: 0049-341-235-

10 451235; e-mail: matthias.kaestner@ufz.de 


\section{Abstract}

14 Degradation tests with radio or stable isotope labeled compounds enable the detection of the formation of 15 non-extractable residues (NER). In PBT and vPvB assessment, remobilisable NER are considered as a 16 potential risk while biogenic NER from incorporation of labeled carbon into microbial biomass are treated 17 as degradation products. Relationships between yield, released $\mathrm{CO}_{2}$ (as indicator of microbial activity and 18 mineralization) and microbial growth can be used to estimate the formation of biogenic NER. We provide a 19 new approach for calculation of potential substrate transformation to microbial biomass (theoretical yield) 20 based on Gibbs free energy and microbially available electrons. We compare estimated theoretical yields 21 of biotechnological substrates and of chemicals of environmental concern with experimentally determined 22 yields for validation of the presented approach. A five-compartment dynamic model is applied to simulate 23 experiments of ${ }^{13} \mathrm{C}$-labeled 2,4-D and ibuprofen turnover. The results show that bioNER increases with 24 time, and that most bioNER originates from microbial proteins. Simulations with pre-calculated input data 25 demonstrate that pre-calculation of yields reduces the number of fit parameters considerably, increases 26 confidence in fitted kinetic data and reduces the uncertainty of the simulation results.

28 Key words: bound residues, modeling, Gibbs free energy, pesticides, carbon conversion, carbon 29 turnover, microbial biomass, Nernst, NER assessment, OECD tests. 
31 Toc Art

32

33

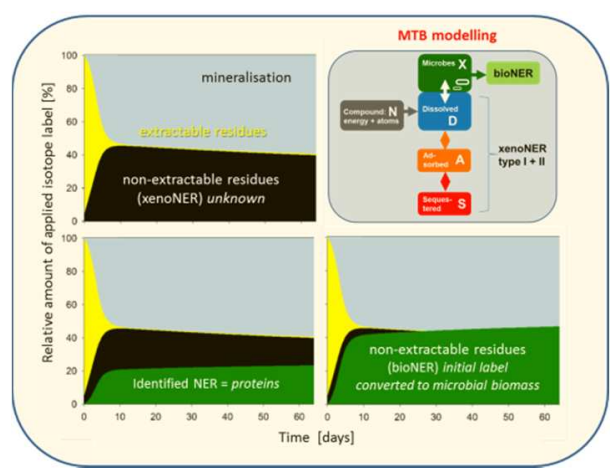

34 
Degradation is a key parameter in risk assessment and registration of industrial chemicals, veterinary medicinal products and pesticides. ${ }^{1-5}$ Microbial degradability tests are often performed with radio-labeled tracer compounds. Guidelines have been developed for fate assessment in water, sediments and soil, e.g., OECD $304,307,308$ and $309 .^{6-9}$ For the interpretation of results, concepts for modeling the turnover kinetics have been developed. ${ }^{10,11}$ Unfortunately, there is still no robust and reliable way to predict the fate of organic molecules in environmental matrices in terms of biotic transformation, mineralization, conversion to microbial biomass and the formation of so-called non-extractable residues (NER). ${ }^{12}$

Chemicals may persist in the environment due to several reasons. Relatively well studied is the persistence due to limited bioavailability. Chemicals being strongly adsorbed or sequestered in soil and sediments are often not available for biodegradation. ${ }^{12-15}$ Examples are the five- or six-ring polycyclic aromatic hydrocarbons. Chemicals newly introduced to the biosphere may persist due to the absence of enzymes capable of transforming such compounds. However, after some time for adaptation microbes can "learn" to degrade recalcitrant compounds. ${ }^{16} \mathrm{~A}$ third reason for persistence is that chemicals are poor growth substrates because they do not provide energy, carbon or nutrients to microbes under the specific environmental conditions. For example, alkanes have persisted over millions of years in reservoirs where no suitable electron acceptor (oxygen) was available. Under aerobic conditions, alkanes are excellent substrates with higher microbial biomass yields than glucose. ${ }^{17,18}$ For chlorinated solvents, e.g. trichloroethylene (TCE), the opposite was observed: the chemical provides no energy to microbes under aerobic conditions and is therefore quite persistent, while it can be reductively dehalogenated as electron acceptor in anaerobic groundwater. ${ }^{19}$ Another reason for persistence of chemicals can be toxic or inhibitory effects on the microorganisms. ${ }^{20,21}$

In the PBT assessment of industrial chemicals and of veterinary pharmaceuticals, NER are differentiated into remobilisable and irreversibly bound fractions. The irreversibly bound fraction is assessed as a potential removal pathway, while the remobilisable fraction is considered a potential risk for the environment. ${ }^{5}$ Remobilisable NER are sequestered compounds (type I NER) and covalently bound parent compounds or metabolites (NER type II), which may be slowly released. The third fraction is labeled 
63 fixed in soil organic matter (SOM) derived from decaying microbial biomass (type III NER). These biogenic 64 NER (bioNER) do not constitute any risk. ${ }^{12}$ There is thus a need to distinguish harmless, irreversibly 65 bound bioNER from potentially toxic and remobilisable NER (i.e., type I and type II NER) in the risk assessment of chemicals.

Determining the microbial biomass yield derived from degradation of a chemical sheds light into the "black box' of NER. The microbial yield is defined as mass of microbes that can grow on a given amount of substrate (unit $\mathrm{g}$ microbial biomass dry weight per $\mathrm{g}$ substrate, $\mathrm{g} \mathrm{g}^{-1}$ ). ${ }^{18}$ However, most studies with labeled carbon compounds typically express results as $\mathrm{g} C$ per $\mathrm{g} \mathrm{C}$, and we report these values with their original unit. The unit conversion is shown in the SI. The yield multiplied by the enzymatic substrate removal determines the growth rate of a microbe. High yield can therefore be an indication for the biodegradability of a substrate. Several methods to estimate theoretical microbial yields of a substrate from its energy of formation (Gibbs free energy) have been developed. ${ }^{22-26}$

The yield can be used to predict the likely range of bioNER formed during degradation of environmental chemicals. We i) provide a relationship between formation of bioNER, $\mathrm{CO}_{2}$ release and yield; ii) present a new and pathway-independent method to estimate yields from thermodynamics combined with an approach to account for the electrons usable by degrading microbes; iii) confirm the yield estimates by comparison to results derived with existing methods ${ }^{23}$ and to measured yields of easily degradable carbohydrates, pesticides and other chemicals of environmental concern. iv) Finally, we use the estimated yields as input to the simulation of 2,4-D and ibuprofen biodegradation under formation of microbial biomass, study the performance of the simulation, and compare pre-calculated kinetic parameters with data derived by pure model fit. Data were provided from experimental degradation studies with multilabeled compounds $\left({ }^{14} \mathrm{C},{ }^{13} \mathrm{C}\right)$ in soil. ${ }^{27-29}$

\section{Methods}




$$
\frac{d m}{d t}=v_{\max } \times \frac{a}{K_{M}+a} \times X
$$

90 where $m$ is the mass of chemical substrate metabolized $(\mathrm{g}), X$ is the bacterial mass ( $\mathrm{g}$ bacteria), $t$ is time

91 (d), $v_{\max }\left(\mathrm{g}\right.$ substrate $\mathrm{g}$ bacteria $\left.{ }^{-1} \mathrm{~d}^{-1}\right)$ is the maximal substrate consumption rate, $a$ is the chemical activity

92 of the substrate (equivalent to the truly dissolved concentration) $\left(\mathrm{g} \mathrm{m}^{-3}\right) ;^{32} K_{\mathrm{M}}\left(\mathrm{g} \mathrm{m}^{-3}\right)$ is the chemical 93 activity at which the substrate consumption rate is half of its maximum (half saturation or Michaelis-

\section{Menten constant).}

The yield $Y\left(\mathrm{~g} \mathrm{~g}^{-1}\right)$ connects metabolism and growth:

$$
\mu_{\max }=v_{\max } \times Y
$$

where $\mu_{\max }$ is the maximum growth rate $\left(\mathrm{d}^{-1}\right)$. Microbes use part of the energy gained from the substrate for growth, and part for maintenance purposes. Experimentally observed net yields equal the true yield minus cell decay. Introducing a term for cell decay or maintenance into the Monod equation for microbial growth leads to eq. $3:^{33}$

$$
\frac{d X}{d t}=\frac{\mu_{\max } a}{K_{M}+a} \times X-b \times X
$$

where $d X / d t$ is the change of microbial biomass with time (g microbial biomass $d w$ per day), and $b$ is the decay rate of microbes (death rate, $\mathrm{d}^{-1}$ ). For the calculation of the fate of chemicals in soils or sediments, a two-compartment-sorption mode ${ }^{34,35}$ calculating rapid (adsorption) and slow (sequestration) kinetics was combined with the equations for microbial metabolism and growth (eqs. 1 and 3 ). ${ }^{12,36}$ The complete model is described in the Supporting Information (SI).

\section{Carbon budget and calculation of bioNER}

Few experimental studies deliver compound concentrations and biomass formation in a resolution that allows fitting of dynamic models to the data. In degradation studies according to OECD guidelines, only

111 the fractions of NER, $\mathrm{CO}_{2}$ and metabolites at the end of the experiment are reported. ${ }^{37}$ Some general 
112 rules and patterns can be derived concerning the distribution of the initially applied labeled carbon and the 113 formation of biomass (here all units are $\mathrm{g} \mathrm{C}$ ).

114 We define $S$ as the total mineralized substrate, $S$ is initial amount of labeled carbon minus non115 metabolized parent compound minus intermediate metabolites and minus NER ${ }^{1, \text { II }}$. NER ${ }^{1, \text { II }}$ denotes non116 extractable residues due to sequestration (I) and co-valent binding (II). ${ }^{12}$ The biomass produced from 117 mineralization of the substrate is per definition the yield, hence, as long as growth alone is considered, $\mathrm{X}=$ $118 \mathrm{Y} \mathrm{S}$. The remaining labeled carbon is oxidized to carbon dioxide, thus $\mathrm{CO}_{2}=(1-\mathrm{Y}) \mathrm{S}$. Under these 119 assumptions, the ratio of $\mathrm{X}$ to $\mathrm{CO}_{2}$ is

$$
\frac{[X]}{\left[\mathrm{CO}_{2}\right]}=\frac{Y}{(1-Y)}
$$

The labeled carbon fixed in biomass due to substrate mineralization is part of the bioNER. Eq. 4 does not take decay of biomass into consideration. Earlier long-term studies ${ }^{38-40}$ over 224 days showed that microbial necromass is a significant source of non-living soil organic matter. In these experiments, approximately $40 \%$ of the labeled carbon initially fixed in biomass $X$ (mainly the protein fraction) turned into SOM (which also is part of bioNER) and 10\% remained within living biomass $\mathrm{X}$. It follows that for $\mathrm{t} \rightarrow$ $\infty$ the fraction $f$ (approximately 0.5 ) of the decaying $X$ turns into bioNER, and $1-f$ forms $\mathrm{CO}_{2}{ }^{40}$ The resulting ratio of bioNER to $\mathrm{CO}_{2}$ in long-term experiments with decomposition of dead biomass (and neglecting slow decomposition of $\mathrm{SOM}$ to $\mathrm{CO}_{2}$ ) is

$$
\frac{[\text { bioNER }]}{\left[\mathrm{CO}_{2}\right]}=\frac{f \times Y}{(1-Y)+(1-f) \times Y}
$$

\section{Yield estimates}

The microbial yield of a substrate can be estimated from thermodynamics or from empirical equations. Approaches for yield estimation have been presented and tested by a number of researchers. ${ }^{22-24,26,41}$ The approaches of $\mathrm{McCarty}{ }^{23}$ and Xiao and vanBriesen ${ }^{26}$ require information on the metabolic pathway of the compound, which is often not given for environmental chemicals' degradation. Therefore, we based our estimates of yields on a modified approach of Diekert ${ }^{22}$, which uses the Gibbs free energy of formation 
and the structural formula. We modified the method by specifying how much of the formation energy can

138 be used by microbes.

Microbial Turnover to Biomass (MTB) - a pathway-independent thermodynamic yield estimation method

The approach considers that a substrate can be utilized for anabolism and catabolism:

$$
N=N_{\text {anabolic }}+N_{\text {catabolic }}=1 / Y
$$

where $N$ is the nutritional value ( $\mathrm{g}$ substrate needed per $\mathrm{g}$ microorganism formed), the inverse of yield $\mathrm{Y}$ :

$$
\frac{1}{Y}=\frac{1}{Y_{\text {anabolic }}}+\frac{1}{Y_{\text {catabolic }}}
$$

The yield associated to anabolism is

$$
Y_{\text {anabolic }}=\frac{n_{c} \times M_{C}}{f_{C} \times M_{S}} \quad\left[\mathrm{~g} \text { microbial biomass } \mathrm{dw} \mathrm{g}^{-1} \text { substrate }\right]
$$

where $n_{\mathrm{c}}$ is mol $\mathrm{C}$ per mol substrate, $M_{\mathrm{C}}$ and $M_{\mathrm{S}}$ are the molar masses of carbon (index $\mathrm{C}$ ) and of substrate (index $\mathrm{S}$ ), respectively, and $f_{C}$ is fraction of $C$ in bacterial dry weight (default $0.53 \mathrm{~g}$ carbon g ${ }^{-1}$ microbial biomass $\mathrm{dw}){ }^{23}$

\section{Catabolism}

154 The yield due to catabolic energy gain can be calculated in five steps.

155 Step i) Free energy of the reaction: The free energy of the reaction (change of Gibbs free energy, $\mathrm{kJ} \mathrm{mol}^{-1}$ ) 156 is the sum of the Gibbs free energy of formation of products minus educts:

$$
\Delta G_{r}^{0^{\prime}}=\sum \Delta G_{f \text { products }}^{0^{\prime}}-\sum \Delta G_{f \text { educts }}^{0^{\prime}}
$$


158 where $G^{0}$ is the Gibbs free energy (subscript $f$ for formation, $r$ for reaction) at standard-state conditions (1 $159 \mathrm{~mol} \mathrm{~L}{ }^{-1}$, indicated by superscript 0 ) and at a $\mathrm{pH}$ of 7 (indicated by superscript '). At activities differing from $1601 \mathrm{~mol} \mathrm{~L}^{-1}$, the change of Gibbs free energy of the reaction $\Delta G_{r}^{\prime}$ is

$$
\Delta G_{r}^{\prime}=\Delta G_{r}^{0^{\prime}}+R T \ln \left(\frac{[\text { products }]}{[\text { educts }]}\right)
$$

where $R\left(8.314 \mathrm{~J} \mathrm{~mol}^{-1} \mathrm{~K}^{-1}\right)$ is the universal gas constant and $T(\mathrm{~K})$ is the absolute temperature.

Step ii) Electron transfer during the reaction (Nernst equation): The Nernst equation states that the change of Gibbs free energy $\Delta G_{r}$ is related to the number of electrons $n$ transferred during the reaction, and the redox potential $E(V)$ of the reaction:

$$
\Delta G_{r}=n \times F \times E
$$

where $F$ is the Faraday constant. The number of electrons $n$ transferred in the reaction can be calculated from the change of the oxidation state (OS) of carbon during the reaction,

$n=\left(\mathrm{OS}_{\text {Product }}-\mathrm{OS}_{\text {Substrate }}\right) \times n_{\mathrm{C}}$

where $n_{\mathrm{C}}$ is again the carbon atoms in the substrate (mol C per mol substrate) which is the same as the moles of $\mathrm{CO}_{2}$-molecules formed during complete mineralization. The oxidation state of carbon in the substrate is:

$$
O S_{\text {Substrate }}=\frac{-1 \times H+2 \times O+3 \times N-3 \times P+2 \times S+1 \times C l}{n_{C}}
$$

where the letters stand for the number of the respective atoms in the molecule. After complete oxidation to $\mathrm{CO}_{2}$, the carbon in the product has the oxidation state 4 , hence $\mathrm{OS}_{\text {Product }}=+4$.

Step iii) Energy available for the microbe: During biological oxidation, the organisms can use only some types of electron transfers. The free energy of the reaction is thus the upper limit ("maximum") for the energy that can be provided by the chemical. The maximum energy gained by the organism during catabolism may be considerably lower than that. As a general rule, when compounds containing hydrogen atoms connected to carbon atoms are oxidized to $\mathrm{CO}_{2}$ and $\mathrm{H}_{2} \mathrm{O}$, the electrons transferred in this reaction 


$$
Y_{\text {catabolic }}=\frac{\beta \times Y_{\mathrm{ATP}}}{M_{\mathrm{S}}}=\frac{n_{\mathrm{bio}}}{n} \times \frac{\Delta G_{r}^{\prime}}{-80 \mathrm{~kJ} / \mathrm{mol}} \times \frac{Y_{\mathrm{ATP}}}{M_{\mathrm{S}}}
$$

$$
\beta=\frac{\Delta G_{b i o}^{\prime}}{-80 \mathrm{~kJ} / \mathrm{mol}}
$$

Step v) Catabolic energy is used for the formation of new cell material: The produced ATP provides the energy to form new cell material. ${ }^{41} Y_{\text {ATP }}$ is the microbial biomass $\mathrm{dw}$ that can be formed per mol ATP. ${ }^{41}$ Diekert ${ }^{22}$ provided a range from $2\left(\mathrm{CO}_{2}\right)$ to 12 (glucose) g microbial biomass dw per mol ATP. Hence, we use the value of $5 \mathrm{~g}$ microbial biomass $\mathrm{dw} \mathrm{mol}^{-1}$ ATP as default for xenobiotic chemicals, but higher values for compounds similar to glucose (for details, see SI). The yield due to catabolic energy gain can finally be calculated by

$$
Y_{\text {catabolic }}=\frac{\beta \times Y_{A T P}}{M_{S}} \quad\left[\mathrm{~g} \text { microbial biomass } \mathrm{dw} \mathrm{g}^{-1} \text { substrate }\right]
$$


201 The more detailed approaches of McCarty $^{23}$ and Xiao and vanBriesen ${ }^{26}$ estimate $\beta$ dependent on the 202 biochemical pathway. Knowledge of the pathway is not required in the method presented because all 203 substrate used for catabolic yield is completely oxidized to $\mathrm{CO}_{2}$.

The estimation of yields is commonly applied in biotechnology or wastewater treatment. In environmental chemistry, it has been used by Helbling et $a l .{ }^{42}$ to estimate the yields of two pesticides and by Yuan and vanBriesen ${ }^{43}$ to estimate the yield of two chelating agents. First, we investigated the performance and the variance of results of the estimation methods with common substrates in biotechnological applications, for which measured yields are widely available. Second, we applied the method to a set of chemicals of environmental concern. The selection of chemicals for this study was based on: i) availability of measured data on bioNER (2,4-D, ibuprofen), ii) availability of biomass yield data (nitrilotriacetic acid [NTA], linuron, carbofuran, toluene), iii) knowledge on specific degradation pathways, electron acceptors or persistence

214 (pentachlorophenol PCP, carbon tetrachloride, trichloroethene, DDT), and iv) availability of Gibbs free 215 energies of formation (Table S2).

\section{Brief description of experiments}

218 Nowak et al. ${ }^{27,28}$ thoroughly balanced the formation of bioNER in a fate study with the ${ }^{13} \mathrm{C}$-labeled 219 pesticide 2,4-D and the medical drug ibuprofen in soil. The authors also analysed the amount of ${ }^{13} \mathrm{C}$ 220 converted to total amino acids (tAA), total fatty and phospholipid fatty acids (PLFA). The tAA increased 221 over time although the PLFA as marker for living biomass declined already after one (2,4-D) to three 222 (ibuprofen) weeks. The details of the turnover experiments are provided in Nowak et al. ${ }^{27,28}$; the results of 223 the experiments are shown in Tables S9 and S10. 
2,4-D and ibuprofen experiments were simulated to confirm the relation between yield and bioNER

227

228

229

230

231

232

233

234 formation. For a detailed description of model and input data see SI S2. The model is composed of five compartments describing the five possible states of labeled carbon: dissolved (D), adsorbed (A), sequestered $(\mathrm{S})$ state, or (following metabolism) carbon dioxide $\left(\mathrm{CO}_{2}\right)$ and living and dead biomass $(X$ and $\left.X_{d e a d}\right)$. The model was implemented as a set of ordinary differential equations (ODEs) in MATLAB. The model was also successfully implemented in Microsoft Excel and produced equal results. The calculated sum of living and dead biomass was considered to be bioNER, and the sum of sequestered fraction and bioNER was compared to measured total NER. No kinetic data were available to separately simulate the formation of type II NER. Hence, any type II NER formed in the experiments were considered to be included in the sequestered compartment of the model. The calculated labeled carbon in the dissolved and adsorbed compartment was compared to the measured extractable labeled carbon.

\section{Calculation and fitting of input parameters}

Input parameters for the simulations were derived as follows. The initial amount of ${ }^{13} \mathrm{C}$ was assumed to be distributed between the dissolved and solid phase according to the soil-water distribution coefficient $\left(K_{d}\right)$. The sequestered fraction was assumed to be equal to the NER measured at $t=0$ and corrected by the reported recovery. $N E R(t=0)$ was subtracted from the calculated ${ }^{13} \mathrm{C}$ present in the solid phase to yield the adsorbed fraction.

We adjusted the input parameters step-wise, similar to Rein et al. ${ }^{36}$ :

Step i) Yield: Calculation with the MTB method.

Step ii) Death rate $b$ : Towards the end of the experiments, the substrate is used up and the microbes decline. Then

$$
\ln \left(\frac{X(t)}{X(0)}\right)_{\text {final phase }} \approx-b t
$$

where $X$ here is the measured concentration of microbial biomass; it is calculated from the measured PLFA times a factor of 20 (5\% content of PLFA in native biomass).

Step iii) Growth: During the initial growth phase the microbial growth can be described as

$$
\ln \left(\frac{X(t)}{X(0)}\right)_{\text {initial phase }}=(\mu-b) t
$$


254 The resulting growth rate $\mu$ at given time $t$ is used to estimate $\mu_{\max }$ (SI 3.2).

255 Step iv) Half-saturation constant: For 2,4-D, a literature value for the ratio $\mu_{\max } / K_{M}$ is given in Tuxen et 256 al. ${ }^{44}$. For ibuprofen, $K_{M}$ was fitted using the $\mathrm{CO}_{2}$ development as criterion.

257 Step v) Initial degrader biomass: $X(0)$ was adjusted to fit the peak biomass concentration and the lag 258 phase. The sum of root mean square errors (RMSE) was used to describe the "goodness-of-fit" (SI S3.3).

During the model calibration against the 2,4-D data we found that the sequestration (slow adsorption, leading to NER) of the labeled carbon of 2,4-D was better described by using the $K_{O C}$ of $2,4-$ dichlorophenol (2,4-DCP) instead of the $K_{O C}$ of the parent compound 2,4-D. 2,4-DCP is the transformation product of 2,4-D and has a $K_{O C}$ much higher than 2,4-D. For the rapid adsorption (part of the extractable

${ }^{13} \mathrm{C}$ ), the $K_{O C}$ of 2,4-D was kept. It is well known that chlorinated phenols tend to form abiotic NER, ${ }^{12}$ thus the better fit of the 2,4-DCP $K_{\mathrm{OC}}$ may provide an indication for NER type II bonding via covalent bonds triggered by oxidative coupling. The most appropriate way to accommodate this change would be the inclusion of step-wise degradation (e.g., 2,4-D to 2,4-DCP to $\mathrm{CO}_{2}$ ), but this increase in model complexity would not be justified by the available data.

Uncertainty analysis and parameter identification

Aside pre-calculation, two optimization routines were used for calibration of $v_{\max }, K_{\mathrm{OC}}, X(0), Y$, and $K_{\mathrm{M}}$

272 (only for ibuprofen). The Pattern Search optimization function is an algorithm that finds local minima from

273 a mesh around the initial values and stops when the optimization function cannot be further minimized. ${ }^{45}$

274 The Bayesian optimization method DiffeRential Evolution Adaptive Metropolis algorithm (DREAM $\left(\mathrm{Zss}^{4}\right)^{46,47}$

275 uses the Bayesian framework and also allows for the assessment of uncertainties related to the parameter 276 estimates and the model predictions. The Bayesian optimization was done with and without $Y$ as a pre277 calculated parameter in order to assess the effect of its inclusion on the parameter estimation and on the 278 uncertainty of the model predictions. For further details on the parameter settings see the SI (S4). 
Table 1 and Table 2 list the observed and estimated yields of substrates relevant to biotechnology (unit $\mathrm{g}$ $\mathrm{C}^{-1} \mathrm{C}$ ) and of chemicals of environmental concern (unit $\mathrm{g}$ microbial biomass $\mathrm{dw} \mathrm{g}^{-1}$ substrate). The biotechnological substrates are easily degradable compounds for which experimental yield data are available. ${ }^{48}$ Both the TEEM2 ${ }^{23}$ and the presented MTB yield estimation methods give relatively close estimates with a mean absolute error (MAE) of less than $0.1 \mathrm{~g} \mathrm{C} \mathrm{g}^{-1} \mathrm{C}$. Few experimental yield data are available for chemicals of environmental concern. The estimates are less accurate, with the highest deviation for linuron, which had a very low measured yield. ${ }^{42}$ Despite its simplicity, the MTB method overall gave results with lower deviation compared to TEEM2 for the chemicals of environmental concern.

\section{<Table 2>}

\section{Dynamic model simulations}

295 Figure 1 shows the experimental and the simulation results for ${ }^{13} \mathrm{CO}_{2}$, extractable ${ }^{13} \mathrm{C}$ (dissolved and adsorbed) and non-extractable ${ }^{13} \mathrm{C}$ (which is the sum of ${ }^{13} \mathrm{C}$-label sequestered and in living or dead biomass). For both compounds, the model with pre-calculated input data is able to reasonably describe the fate of ${ }^{13} \mathrm{C}$ in the different compartments. However, $\mathrm{CO}_{2}$ and $\mathrm{NER}$ are predicted to increase at an earlier time point than observed. For 2,4-D, this can be seen already at the first data points, whereas for ibuprofen it is evident after 28 days. Based on the Michaelis-Menten equation, it was assumed that the formation of $\mathrm{CO}_{2}$ and new biomass occurs as soon as the labeled compound is transformed. In reality, internal storage of metabolites and $\mathrm{HCO}_{3}{ }^{-}$delays the release of $\mathrm{CO}_{2}$. This may be overcome by the introduction of new parameters; only, this would considerably increase model complexity which was not desired. In the beginning of the simulation, most NER are sequestered, but towards the end of the simulation, the NER originate mainly from living and dead biomass.

306 The experimentally determined extractable ${ }^{13} \mathrm{C}$-ibuprofen was declining within four weeks (Fig. 1b). The 307 extractable ${ }^{13} \mathrm{C}$-label had initially similar values but remained relatively high throughout the experiment. 308 After 90 days, $13.4 \%$ of the ${ }^{13} \mathrm{C}$ was detected in the solvent-extractable portion, but only $0.5 \%$ was ${ }^{13} \mathrm{C}$ - 
309 ibuprofen (Girardi et al. ${ }^{29}$, Table S10). This indicates rapid formation of transformation products and 310 incomplete mineralization with only little 2-hydroxy-ibuprofen (Table S10).

312 Figure 2 depicts the simulated living biomass $(X)$, dead biomass $\left(X_{\text {dead }}\right)$ and the sum of both. This is 313 compared to the measured ${ }^{13} \mathrm{C}$ in PLFA multiplied with a factor 20 as a marker for living biomass (5\% 314 PLFA content), and to the measured ${ }^{13} \mathrm{C}$-label in tAA. Living biomass contains about $50 \%$ proteins (amino 315 acids), hence also tAA multiplied with a factor of two was plotted. It can be seen that PLFA/0.05 and 316 tAA/0.5 as well as the simulated sum of $X$ and $X_{\text {dead }}$ are close until day 4 (2,4-D, Fig. 2a) or day 14 317 (ibuprofen, Fig. 2b), as long as the living biomass predominates. Later PLFA declines, which indicates a 318 decline of living biomass $X$. The dotted line in Figure 2 is the decay halftime $(\ln 2 / b)$ after maximum 319 measured PLFA. The line indicates where $>50 \%$ of microbes have died. From this point, the simulated 320 sum of $X$ and $X_{\text {dead }}$ is much closer to tAA than to tAA/0.5. In decaying microbes, labile constituents like sugars and fatty acids are turned over first and the more stable amino acids (tAA) in proteins persist (also see SI S2.13). ${ }^{39,40}$ Thus, towards the end of the simulation, the sum of $X$ and $X_{\text {dead }}$ is dominated by proteins and should be compared to tAA and not to tAA/0.5.

326 The measured ${ }^{13} \mathrm{CO}_{2}$ release in the $2,4-\mathrm{D}$ experiment was $57.6 \%$ of the initially applied ${ }^{13} \mathrm{C}$ (SI Table S9), 327 and the calculated yield of 2,4-D was $0.28 \mathrm{~g}^{13} \mathrm{C} \mathrm{g}^{-1}{ }^{13} \mathrm{C}$. Using these values in the equation for the ratio of biomass growth to $\mathrm{CO}_{2}$ production (eq. 4) we calculated that $22 \%$ of the applied ${ }^{13} \mathrm{C}$-label was fixed in the biomass. The measured tAA was at $23.3 \%$ (SI Table S9). For ibuprofen, with a measured ${ }^{13} \mathrm{CO}_{2}$-release of $45.2 \%$ (Table S10) and a calculated yield of $0.43 \mathrm{~g}^{13} \mathrm{C} \mathrm{g}^{-1}{ }^{13} \mathrm{C}$, the calculated ${ }^{13} \mathrm{C}$-label in biomass was $34 \%$ (measured tAA: $28.4 \%$ ). In the case of these two experiments, the measured ${ }^{13} \mathrm{C}$-label within amino acids (tAA) was remarkably constant towards the end of the experimental period, and there was no need to consider turnover of dead biomass. The calculated ${ }^{13} \mathrm{C}$-label fixed in bioNER with eq. 5 was $9.4 \%(2,4-$ D) and $12.4 \%$ (ibuprofen). Once the fraction of bioNER is known from $Y$ and $\mathrm{CO}_{2}$, the potentially remobilisable NER type I and type II can be quantified from the total NER. In the PBT/vPvB assessment of 
336 chemicals, the bioNER fraction can be subtracted from the total NER and counted as degraded. In a 337 follow-up study, we used this method to estimate the bioNER for 40 chemicals of environmental concern. ${ }^{49}$

$339<$ Figure 1>

$340<$ Figure 2>

\section{Discussion}

$343 \quad$ Yield estimates

344 We presented the new MTB approach for estimation of microbial biomass yields. Considering the 345 variability of the experimental data, this approach showed fairly similar deviations from experimental yield 346 data in comparison to the more advanced and widely applied TEEM2 approach ${ }^{23}$, without the need for 347 specific information about the catabolic pathway, primary oxidation processes or $\mathrm{N}$ sources. For 348 environmentally relevant chemicals and pesticides the deviation of the experimental yields is even lower 349 than estimated with the MTB . The MTB approach can be applied for many tasks, e.g. yield assessment in 350 biological wastewater treatment or maximum transfer of labeled carbon into microbial biomass and 351 bioNER assessment, as shown with the simulations. Yield estimates can thus contribute to an improved 352 risk assessment of environmentally relevant chemicals. The method may be added as a module in 353 biodegradation databases (like EAWAG-BBD/PPS http://eawag-bbd.ethz.ch/, KEGG 354 http://www.genome.jp/) and QSAR approaches (like ChemProp www.ufz.de/ecochem/chemprop or EPI 355 suite https://www.epa.gov/tsca-screening-tools/epi-suitetm-estimation-program-interface). Combined with 356 the unified model for sorption and biodegradation (Kästner et al. ${ }^{12}$, Rein et al. ${ }^{36}$, and this study) the MTB 357 yield estimation method can be used for modeling the entire turnover process of a chemical in the 358 environment. 
361 Yield estimations are rarely applied to chemicals of environmental concern. One exception is the study of 362 Helbling et al. ${ }^{42}$ with linuron and carbofuran. The estimated theoretical yields for carbofuran are $0.51 \mathrm{~g} \mathrm{~g}^{-1}$ 363 (MTB method) or $0.59 \mathrm{~g} \mathrm{~g}^{-1}$ (TEEM2 method) and $0.41 \mathrm{~g} \mathrm{C} \mathrm{g}^{-1} \mathrm{C}=0.50 \mathrm{~g} \mathrm{~g}^{-1}$ with the related adapted 364 TEEM1 method. ${ }^{42}$ The experimentally determined yield of carbofuran was $0.52 \mathrm{~g} \mathrm{~g}^{-1}\left(0.42 \mathrm{~g} \mathrm{C} \mathrm{g}^{-1} \mathrm{C}\right)$. The 365 experimental yields obtained for linuron in the Helbling et al. ${ }^{42}$ study were very low $\left(0.06 \mathrm{~g} \mathrm{C} \mathrm{g}^{-1} \mathrm{C}=0.05 \mathrm{~g}\right.$ $\left.366 \mathrm{~g}^{-1}\right)$ despite a theoretical yield similar to carbofuran $\left(0.40 \mathrm{~g} \mathrm{C} \mathrm{g}^{-1} \mathrm{C}=0.33 \mathrm{~g} \mathrm{~g}^{-1}\right)$. Maximum growth rates $367 \mu_{\max }$ were determined to be $7.8 \mathrm{~d}^{-1}$ (carbofuran) and $1.3 \mathrm{~d}^{-1}$ (linuron), corresponding to a $v_{\max }=15.1$ and

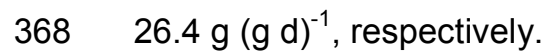

369 Kinetic parameters and yields of polycyclic aromatic hydrocarbons PAH have been determined in several 370 studies. Wick et al. ${ }^{50}$ grew Mycobacterium sp. LB501T on solid anthracene and obtained yields between 3710.158 and $0.196 \mathrm{~g} \mathrm{~g}^{-1}$ and $v_{\max }$ of $\left.18.4 \mathrm{~g} \mathrm{(g} \mathrm{d}\right)^{-1}$. Adam et al. ${ }^{51}$ found for the growth of three degrader 372 strains on phenanthrene the same yield of $0.21 \mathrm{~g} \mathrm{~g}^{-1}$, with $v_{\max }$ from 12 to $18 \mathrm{~g}(\mathrm{~g} \mathrm{~d})^{-1}$. Rein et al. ${ }^{36}$ tested 373 growth of Mycobacterium sp. on phenanthrene and pyrene and found yields from 0.20 to $0.32 \mathrm{~g} \mathrm{~g}^{-1}$ and

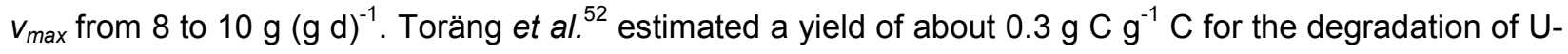
ring-labeled phenoxy-acetic acids (MCPP and 2,4-D) using the ${ }^{14} \mathrm{C}-\mathrm{MPN}$ (most probable number) ${ }^{53}$

Most of the experimental yields (Table 2) are lower while $v_{\max }$-values and growth rates are higher than those obtained here (Table 3), and there could be several reasons for this: In these studies, known pure degrader strains were tested under optimal nutrient conditions, which explains the faster growth and the lower $K_{M}$-values compared to the studies simulated here, in which natural microbial communities were used according to the OECD guidelines. Compound turnover and the related yields in experiments with natural inoculum and multiple substrates may be lower than single-strain/single-substrate experiments due to the enrichment of metabolites (incomplete mineralization) or to the use of multiple carbon sources derived from dissolved organic carbon or SOM. ${ }^{31,42}$

The pre-calculated model input parameters were compared to those fitted by the $\operatorname{DREAM}_{(\mathrm{Zs})}$ and the Pattern Search algorithms (Table 3). For 2,4-D, the fitted yields are higher than the pre-calculated one. 
Conversely, fitted yields for ibuprofen are substantially lower than the pre-calculated theoretical yield, which may be again an indication of incomplete mineralization of ibuprofen. Both $v_{\max }$ and $K_{\mathrm{M}}$ derived by the $\operatorname{DREAM}_{(\mathrm{ZS})}$ algorithm are clearly higher than the pre-calculated values and those derived by the Pattern Search algorithm, and this affects also the $\mu_{\max }$-values. However, the ratio between $v_{\max }$ and $K_{\mathrm{M}}$, which is effectively determining metabolism (eq. 1), is for 2,4-D comparable amongst all four methods. For ibuprofen this ratio is higher for the $\operatorname{DREAM}_{(\mathrm{ZS})}$ algorithm but within a factor of two of the values derived by the other methods. The DREAM $(\mathrm{Zs})$ algorithm returned $K_{\mathrm{OC}}$-values for the 2,4-D simulation that are very close to the $K_{\mathrm{OC}}$ of $2,4-\mathrm{DCP}$. The value found with the Pattern Search algorithm is in between the $K_{\mathrm{OC}^{-}}$ values of 2,4-D and 2,4-DCP. A large disagreement between fitted and pre-calculated values is observed for the $K_{\mathrm{OC}}$ of ibuprofen, where the pre-calculated value was obtained by a regression equation ${ }^{54}$. Without exception, the pre-calculated parameters are within the $95 \%$ credibility interval given by the $\operatorname{DREAM}_{(\mathrm{ZS})}$ method. This gives additional confidence to the identified system kinetics.

A simultaneous fit of all parameters, as it is often done (for example, Brimo et al. ${ }^{55}$ ), can produce a better fit to experimental data. This was also the case in our simulations, where the RMSE of the simulated results was lower when the input parameters were fitted (Table 3). Still, estimating the yield with an independent method showed some advantages for the simulation. The parameter identifiability improved, as can be seen from a decrease of the correlation between the fit parameters (Table S7). Using the criteria of Frutiger et al. ${ }^{56}(r<0.7, \sigma / \mu<0.5)$, all parameters were identifiable via model calibration to the 2,4-D data. For ibuprofen, only $Y, K_{\mathrm{OC}}$, and $K_{\mathrm{M}}$ but not $v_{\max }$ and $X(0)$ were identifiable (Table S8) (details in SI section S4). The largest effect was seen on the uncertainty of the prediction: omitting $Y$ from the fit procedure greatly reduced the uncertainty in the model predictions, as shown by the width of the $95^{\text {th }}$ percentile credibility interval (Figures S5-S8), in particular for NER and $X$. Importantly, as we showed in this study, the knowledge of the yield gives insight into the degradation processes. It is now possible to elucidate the nature of non-extractable residues by a combination of novel analytics, basic principles, and 412 dynamic simulation. 


\section{Acknowledgement}

417 This research Project was financially supported by the Technical University of Denmark and the Helmholtz

418 Centre for Environmental Research UFZ. We thank Fabio Polesel, Pedram Ramin, Frank Dieter Kopinke

419 and Jochen Müller for valuable suggestions to develop the approach.

421 The dynamic degradation model with description is available in a public version at

422 http://www.magicpah.org/links/ or http://homepage.env.dtu.dk/stt/.

423 Supporting Information available comprises: more detailed equations and parameter of the modeling approach. This information is available free of charge via the Internet at http://pubs.acs.org/

The MTB theoretical yield tool is available as excel or Python code on request to the first author.

\section{References}

(1) EU. Regulation (EC) No 1907/2006 of the European Parliament and the Council of 18 December 2006 concerning Registration, Evaluation, Authorisation and Restriction of Chemicals (REACH). Official Journal of the European Union; 2006, L 136.

(2) EU. Regulation (EC) No 1107/2009 of the European Parliament and the council of 21 October 2009

(3) EU. Commission regulation (EU) No $283 / 2013$ setting out the data requirements for active substances, in accordance with Regulation (EC) No 1107/2009 of the European Parliament and the Council concerning the placing of plant protection products on the market. Official Journal of the European Union; 2013, L 93/1. 
440 (4) EMA European Medicines Agency. Guideline on the assessment of persistent, bioaccumulative and toxic (PBT) or very persistent and very bioaccumulative (vPvB) substances in veterinary medicinal products. September 2015

443

(5) ECHA European Chemical Agency. Guidance on Information Requirements and Chemical Safety Assessment, Chapter R.11: Endpoint specific guidance (PBT/vPvB assessment). Draft version

(6) OECD. Test No. 304A: Inherent Biodegradability in Soil. OECD Publishing Paris; 1981. DOI 10.1787/9789264070448-en

(7) OECD. Test No. 307: Aerobic and Anaerobic Transformation in Soil. OECD Publishing: Paris 2002a. DOI 10.1787/9789264070509-en

(8) OECD. Test No. 308: Aerobic and Anaerobic Transformation in Aquatic Sediment Systems. OECD

(9) OECD. OECD Test No. 309: Aerobic Mineralisation in Surface Water - Simulation Biodegradation Test. OECD Publishing: Paris 2004. DOI 10.1787/9789264070547-en

(10) Matthies M.; Witt J.; Klasmeier J. Determination of soil biodegradation half-lives from simulation testing under aerobic laboratory conditions: A kinetic model approach. Environ. Pollut. 2008, 156, 99-105.

(11) Honti, M.; Hahn, S:; Hennecke, D.; Junker, T.; Shrestha, P.; Fenner, K. Bridging across OECD 308 and 309 data in search of a robust biotransformation indicator. Environ. Sci. Technol. 2016, 50 (13), 6865-6872; DOI 10.1021/acs.est.6b01097

(12) Kästner, M.; Nowak, K. M.; Miltner, A.; Trapp, S.; Schäffer, A. Classification and modelling of nonextractable residue (NER) formation of xenobiotics in soil - a synthesis. Crit. Rev. Env. Sci. Tec. 2014, 44 (19), 1-65.

(13) Alexander M. Aging, bioavailability, and overestimation of risk from environmental pollutants. Environ. Sci Technol. 2000, 34, 4259-4264.

(14) Bosma, T. N.; Middeldorp, P. J. M.; Schraa, G.; Zehnder, A. J. B. Mass transfer limitation of biotransformation: Quantifying bioavailability. Environ. Sci. Technol. 1997, 31, 248-252.

(15) Katayama, A.; Bhula, R.; Burns, G. R.; Carazo, E.; Felsot, A.; Hamilton, D.; Harris, C.; Kim, Y.H.; Kleter, G.; Koerdel, W.; Linders, J.; Peijnenburg, J.G.M.W.; Sabljic, A.; Stephenson, R.G.; Racke, 
D.K.; Rubin, B.; Tanaka, K.; Unsworth, J.; Wauchope, R. D. Bioavailability of Xenobiotics in the Soil Environment. In: Reviews of Environmental Contamination and Toxicology; D. M. Whitacre (Ed.); Springer, New York, 2010; pp 1-86.

(16) Ingerslev, F; Baun, A; Nyholm, N. Aquatic biodegradation behavior of pentachlorophenol assessed through a battery of shake flask die-away tests. Environ. Toxicol. Chem. 1998, 17 (9), 1712-1719.

(17) Schlegel, H.G. Allgemeine Mikrobiologie, $5^{\text {th }}$, ed.; Verlag Georg Thieme: Stuttgart, Germany, 1981.

(18) Madigan, M.T.; Martinki, J.; Parker, J. Biology of Microorganisms. International Student Edition Pearson Inc.; 2011.

(19) Heimann, A.C.; Friis, A.K.; Scheutz, C.; Jakobsen, R. Dynamics of reductive TCE dechlorination in two distinct H-2 supply scenarios and at various temperatures. Biodegradation 2007,18 (2), 167179.

(20) Won, W.D.; DiSalvo, L.H.; James, N.G. Toxicity and mutangenicity of 2,4,6-trinitrotoluene and its microbial metabolites. Appl. Environ. Microbiol. 1975, 31, 576-580.

(21) Honeycutt, M.E.; Jarvis, A.S.; McFarland, V.A. Cytotoxicity and mutagenicity of 2,4,6-trinitrotoluene and its metabolites. Ecotoxicol. Environ. Saf. 1996, 35, 282-287.

(22) Diekert G. Grundmechanismen des Stoffwechsels und der Energiegewinnung. In: Umweltbiotechnologie; Ottow, J. C. G.; Bidlingmaier, W. (Eds.); Fischer Verlag, Stuttgart, Germany, 1997; pp 1-38.

(23) McCarty, P. L. Thermodynamic electron equivalents model for bacterial yield prediction: Modifications and comparative evaluations. Biotechnol. Bioeng. 2007, 97 (2), 377-388.

(24) Heijnen, J. J. A new thermodynamically based correlation of chemotrophic biomass yields. Anton. Leeuw. Int. J. G. 1991, 60, 235-256.

(25) vanBriesen, J. M. Evaluation of methods to predict bacterial yield using thermodynamics. Biodegradation 2002, 13 (3), 171-90.

(26) Xiao, J.; VanBriesen, J. M. Expanded thermodynamic true yield prediction model: adjustments and limitations. Biodegradation 2008, 19 (1), 99-127.

(27) Nowak, K.M.; Miltner, A.; Gehre, M.; Schäffer, A.; Kästner, M. Formation and fate of bound residues from microbial biomass during 2,4-D degradation in soil. Environ. Sci. Technol. 2011, 45, 9991006. 
(28) Nowak, K.M.; Girardi, C.; Miltner, A.; Gehre, M.; Schäffer, A.; Kästner, M. Contribution of microorganisms to non-extractable residue formation during biodegradation of ibuprofen in soil. Sci. Tot. Environ. 2013, 445, 377-384.

(29) Girardi, C.; Nowak, K. M.; Carranza-Diaz, O.; Lewkow, B.; Miltner, A.; Gehre, M., Schäffer, A; Kästner, M. Microbial degradation of the pharmaceutical ibuprofen and the herbicide 2,4-D in water and soil - Use and limits of data obtained from aqueous systems for predicting their fate in soil. Sci. Total Environ., 2013, 444, 32-42.

(30) Cornish-Bowden, A. Fundamentals of enzyme kinetics; Portland Press, London, U.K., 1995.

(31) Kovárová-Kovar K.; Egli T. Growth kinetics of suspended microbial cells: From single-substratecontrolled growth to mixed-substrate kinetics. Microbiol. Mol. Biol. Rev. 1998, 62 (3), 646-666.

(32) Trapp, S.; Franco, A.; MacKay, D. Activity-based concept for transport and partitioning of ionizing organics. Environ. Sci. Technol. 2010, 44 (16), 6123-6129

(33) van Uden N. Transport-limited growth in the chemostat and its competitive inhibition; a theoretical treatment. Archiv für Mikrobiologie 1967, 58, 145-154.

(34) Brusseau, M.L.; Larsen, T.; Christensen, T.H. Rate-limited sorption and nonequilibrium transport of organic chemicals in low organic carbon aquifer materials. Wat. Resour. Res. 1991, 27(6), 11371145.

(35) Johnson, M.D.; Keinath II, T.M.; Weber Jr., W.J. A distributed reactivity model for sorption by soils and sediments. 14. Characterization and modeling of phenanthrene desorption rates. Environ. Sci. Technol. 2001, 35,1688-1695.

(36) Rein, A.; Adam, I. K. U.; Miltner, A.; Brummer, K.; Kästner, M.; Trapp, S. Impact of bacterial activity on turnover of insoluble hydrophobic substrates (phenanthrene and pyrene) - Model simulations for prediction of bioremediation success. J. Hazard. Mater. 2016, 306, 105-114.

(37) Barriuso, E.; Benoit, P.; Dubus, I. G. Formation of pesticide nonextractable (bound) residues in soil: Magnitude, controlling factors and reversibility. Environ. Sci. Technol. 2008, 42, 1845-1854.

(38) Kindler, R; Miltner, A; Richnow, H.-H.; Kästner, M. Fate of gram-negative bacterial biomass in soilmineralization and contribution to SOM. Soil Biol. Biochem. 2006, 38, 2860-2870.

(39) Kindler, R.; Miltner, A.; Thullner, M.; Richnow, H.-H.; Kästner M. Fate of bacterial biomass derived fatty acids in soil and their contribution to soil organic matter. Org. Geochem. 2009, 40, 29-37. 
527

(40) Miltner, A.; Bombach, P.; Schmidt-Brücken, B.; Kästner, M. SOM genesis: Microbial biomass a significant source. Biogeochemistry 2012, 111, 41-55.

(41) Thauer, R. K.; Jungermann, K.; Decker, K. Energy Conservation in Chemotrophic Anaerobic Bacteria. Bacteriol. Rev. 1977, 41 (1), 100-180.

(42) Helbling, D.E.; Hammes, F.; Egli, T.; Kohler, H.-P. E. Kinetics and yields of pesticide biodegradation at low substrate concentrations and under conditions restricting assimilable organic carbon. Appl. Environ. Microb. 2014, 80 (4), 1306-1313.

(43) Yuan, Z.; vanBriesen, J. M. Bacterial growth yields on EDTA, NTA, and their biodegradation intermediates. Biodegradation 2008, 19 (1), 41-52; DOI http://doi.org/10.1007/s10532-007-9113-y

(44) Tuxen, N.; De Liptay, J. R.; Albrechtsen, H.-J.; Aamand, J.; Bjerg, P.L. Effect of exposure history on microbial herbicide degradation in an aerobic aquifer affected by a point source. Environ. Sci. Technol. 2002, 36, 2205-2212.

(45) MathWorks 2016. Help to "patternsearch". https://se.mathworks.com/help/gads/patternsearch.html (46) ter Braak, C.J.F.; Vrugt, J.A. Differential evolution Markov chain with snooker updater and fewer chains. Stat. Comput. 2008, 18 (4), 435-446.

(47) Vrugt, J. A. Markov chain Monte Carlo simulation using the DREAM software package: Theory, concepts, and MATLAB implementation, Environ. Model. Softw. 2016, 75, 273-316.

(48) Heijnen, J. J.; Dijken, J. P. In search of a thermodynamic description of biomass yields for the chemotrophic growth of microorganism. Biotechnol. Bioeng. 1992, 39, 833-852.

(49) Brock, A.; Kästner, M.; Trapp, S. Microbial growth yield estimates from thermodynamics and its importance for degradation of pesticides and formation of biogenic non-extractable residues, $S A R$ QSAR Environ. Res., 28:8, 629-650, DOI: 10.1080/1062936X.2017.1365762.

(50) Wick, L.Y.; Colangelo, T.; Harms, H. Kinetics of mass transfer-limited bacterial growth on solid PAHs, Environ. Sci. Technol. 2001, 35, 354-361.

(51) Adam, I. K. U.; Rein, A.; Miltner, A.; Fulgêncio, A. C. D.; Trapp, S.; Kästner, M. Experimental Results and Integrated Modeling of Bacterial Growth on an Insoluble Hydrophobic Substrate (Phenanthrene). Environ. Sci. Technol. 2014, 48 (15), 8717-8726. 
554

(52) Toräng, L.; Nyholm, N.; Albrechtsen, H.-J. Shifts in biodegradation kinetics of the herbicides MCPP and 2,4-D at low concentrations in aerobic aquifer materials. Environ. Sci. Technol. 2003, 37 (14), 3095-3103.

(53) Lehmicke, L. G.; Williams, R. T.; Crawford, R. L.. 14C-most-probable-number method for enumeration of active heterotrophic microorganisms in natural waters. Appl. Environ. Microbiol. 1979, 38 (4), 644-649.

(54) Franco, A.; Trapp, S. Estimation of the soil-water partition coefficient normalized to organic carbon for ionizable organic chemicals. Environ. Toxicol. Chem. 2008, 27 (10), 1995-2004.

(55) Brimo, K.; Garnier, P.; Sun S.; Bertrand-Krajewski, J.-L.; Cebron, A.; Ouvrard, S. Using a Bayesian approach to improve and calibrate a dynamic model of polycyclic aromatic hydrocarbons degradation in an industrial contaminated soil. Environ. Pollut., 2016, 215, 27-37; DOI dx.doi.org/10.1016/j.envpol.2016.04.094

(56) Frutiger, J.; Marcarie, C.; Abildskov, J.; Sin, G. A Comprehensive Methodology for Development, Parameter Estimation, and Uncertainty Analysis of Group Contribution Based Property Models-An Application to the Heat of Combustion. J. Chem. Eng. Data 2016, 61 (1), 602-613.

(57) Chong, N. M.; Tsai, S. C.; Le, T. N. The biomass yielding process of xenobiotic degradation. Bioresource Technol. 2010, 101 (12), 4337-4342.

(58) Oh, Y.-S.; Shareefedeen, Z.; Baltzis, B. C.; Bartha, R. Interactions between benzene, toluene, and pxylene (BTX) during their biodegradation. Biotechnol. Bioeng. 1994, 44, 533-538. 


\section{Tables}

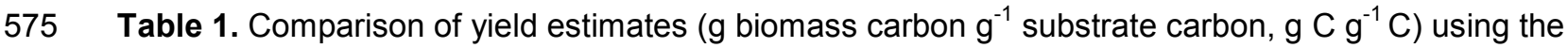
576 TEEM $2^{23}$ and the MTB methods for biotechnological substrates. AE is absolute error and MAE is mean 577 absolute error. Measured yields are taken from ref. 48.

\begin{tabular}{|c|c|c|c|c|c|}
\hline Biotech. substrates & Measured & TEEM2 & $\mathrm{AE}$ & MTB & $\mathrm{AE}$ \\
\hline Acetate $^{-}$ & 0.41 & 0.40 & 0.01 & 0.47 & 0.05 \\
\hline Citrate $^{3-}$ & 0.365 & 0.34 & 0.025 & 0.29 & 0.075 \\
\hline Ethanol & 0.53 & 0.67 & 0.14 & 0.60 & 0.07 \\
\hline Formaldehyde & 0.47 & 0.51 & 0.04 & 0.58 & 0.11 \\
\hline Glucose & 0.61 & 0.48 & 0.13 & 0.61 & 0.0 \\
\hline Glycerol & 0.67 & 0.55 & 0.12 & 0.62 & 0.05 \\
\hline Glyoxylate & 0.22 & 0.27 & 0.05 & 0.27 & 0.05 \\
\hline Methanol & 0.54 & 0.56 & 0.02 & 0.66 & 0.12 \\
\hline Propionate ${ }^{-}$ & 0.48 & 0.47 & 0.01 & 0.50 & 0.02 \\
\hline Pyruvate - & 0.32 & 0.39 & 0.07 & 0.39 & 0.07 \\
\hline MAE & & & 0.0615 & & 0.0615 \\
\hline
\end{tabular}


580 Table 2. Comparison of yield estimates ( $\mathrm{g}$ microbial biomass $\mathrm{dw} \mathrm{g}^{-1}$ substrate, $\mathrm{g} \mathrm{g}^{-1}$ ) using the TEEM2 $2^{23}$ 581 and the MTB methods for chemicals of environmental concern. AE is absolute error and MAE is mean 582 absolute error.

\begin{tabular}{|c|c|c|c|c|c|c|}
\hline Environmental chemicals & Observed & TEEM2 & AE & MTB & $\mathrm{AE}$ & $\begin{array}{l}\text { Reference for } \\
\text { observed } Y\end{array}$ \\
\hline $2,4-D\left({ }^{12} C\right)$ & 0.25 & 0.39 & 0.14 & 0.23 & 0.02 & bl \\
\hline $2,4-\mathrm{D}\left({ }^{13} \mathrm{C}\right.$ ring-labeled $)$ & $0.18 ; 0.25$ & & & & & This study; ${ }^{52}$ \\
\hline 2,4-DCP & 0.30 & 0.41 & 0.11 & 0.21 & 0.09 & bl \\
\hline Benzene & 0.71 & 0.84 & 0.13 & 0.65 & 0.06 & 58 \\
\hline Carbofuran & 0.52 & 0.59 & 0.07 & 0.51 & 0.01 & 42 \\
\hline Carbon tetrachloride & & 0 & & 0 & & Persistent \\
\hline DDT & & 0.42 & & 0.25 & & \\
\hline Ibuprofen $\left({ }^{12} \mathrm{C}\right)$ & 0.43 & 0.61 & 0.18 & 0.62 & 0.19 & This study \\
\hline Ibuprofen $\left({ }^{13} \mathrm{C}\right.$ ring-labeled $)$ & 0.39 & & & & & 28 \\
\hline Linuron & 0.05 & 0.33 & 0.28 & 0.32 & 0.27 & 42 \\
\hline Nitrilotriacetic acid & 0.23 & 0.23 & 0.00 & 0.27 & 0.04 & 43 \\
\hline Pentachlorophenol & & 0.19 & & 0 & & Persistent ${ }^{16}$ \\
\hline Phenanthrene & 0.21 & 0.82 & 0.61 & 0.53 & 0.32 & 51 \\
\hline Pyrene & 0.32 & 0.54 & 0.22 & 0.44 & 0.12 & 36 \\
\hline Trichloroethene & & 0.16 & & 0.11 & & Persistent \\
\hline Toluene & 0.71 & 0.86 & 0.15 & 0.69 & 0.02 & b8 \\
\hline MAE & & & 0.189 & & 0.114 & \\
\hline
\end{tabular}


585 Table 3. Input and fit parameters used for the simulation of degradation experiments of 2,4-D and 586 ibuprofen described in Nowak et al. ${ }^{27,28}$ and Girardi et al. ${ }^{29}$. Parameter values highlighted in bold were not 587 fitted but pre-calculated.

\begin{tabular}{|c|c|c|c|c|c|}
\hline Parameter & unit & $\begin{array}{l}\text { Manual w/ } \\
\text { pre-estimated } \\
\text { yield }\end{array}$ & $\begin{array}{l}\text { Pattern Search } \\
\text { w/o pre- } \\
\text { estimated yield }\end{array}$ & $\begin{array}{l}\text { DREAM w/ pre- } \\
\text { estimated yield } \\
\text { (95\% credibility } \\
\text { interval) }\end{array}$ & $\begin{array}{l}\text { DREAM w/o } \\
\text { pre-estimated } \\
\text { yield } \\
(95 \% \\
\text { credibility } \\
\text { interval) }\end{array}$ \\
\hline $2,4-D$ & & & & & \\
\hline Y & $\begin{array}{l}g^{13} \mathrm{C}_{\text {biomass }}(\mathrm{g} \\
\left.{ }^{13} \mathrm{C}_{\text {substrate }}\right)^{-1}\end{array}$ & $0.28^{a}$ & 0.36 & $0.28^{a}$ & $\begin{array}{l}0.31(0.21 ; \\
0.52)\end{array}$ \\
\hline$b$ & $d^{-1}$ & $0.05^{\mathrm{b}}$ & $0.05^{\mathrm{b}}$ & $0.05^{\mathrm{b}}$ & $0.05^{b}$ \\
\hline$\mu_{\max }$ & $\begin{array}{l}g^{13} \mathrm{C}_{\text {biomass }}(\mathrm{g} \\
\left.{ }^{13} \mathrm{C}_{\text {substrate }} \mathrm{d}\right)^{-1}\end{array}$ & $1.1^{\mathrm{c}}$ & 1.43 & $1.61(0.38 ; 2.72)$ & $\begin{array}{l}1.73(0.40 \\
3.85)\end{array}$ \\
\hline$v_{\max } / K_{\mathrm{M}}$ & $m^{-3}\left(g^{13} C d\right)^{-1}$ & $2.72^{d}$ & $2.08^{d}$ & $2.72^{d}$ & $\begin{array}{l}2.47^{d}(1.45 ; \\
3.61)\end{array}$ \\
\hline$X(0)$ & $\mathrm{g} \mathrm{m}^{-3}$ & 0.172 & 0.28 & $0.87(0.16 ; 1.34)$ & $\begin{array}{l}0.88(0.16 \\
1.4)\end{array}$ \\
\hline$K_{\mathrm{OC}}$ & $\mathrm{L} \mathrm{kg}^{-1}$ & $\begin{array}{l}2,4-D: 71.4^{e} \\
2,4-D C P: 689^{f}\end{array}$ & 300 & $655(218 ; 977)$ & $668(506 ; 836)$ \\
\hline $\begin{array}{l}\text { sum } \\
\text { RMSE }^{g}\end{array}$ & $\mathrm{~g}^{13} \mathrm{C} \mathrm{m}^{-3}$ & 5.57 & 1.56 & 2.17 & 2.13 \\
\hline Ibuprofen & & & & & \\
\hline Y & $\begin{array}{l}g^{13} \mathrm{C}_{\text {biomass }}(\mathrm{g} \\
\left.{ }^{13} \mathrm{C}_{\text {substrate }}\right)^{-1}\end{array}$ & $0.43^{a}$ & 0.28 & $0.43^{a}$ & $\begin{array}{l}0.32(0.11 ; \\
0.53)\end{array}$ \\
\hline$b$ & $d^{-1}$ & $0.03^{b}$ & $0.03^{\mathrm{b}}$ & $0.03^{\mathrm{b}}$ & $0.03^{\mathrm{b}}$ \\
\hline$\mu_{\max }$ & $\mathrm{g}{ }^{13} \mathrm{C}_{\text {biomass }}(\mathrm{g}$ & $0.50^{\mathrm{C}}$ & 0.28 & $1.41(0.18 ; 4.1)$ & $1.34(0.12$ \\
\hline
\end{tabular}


$\left.{ }^{13} \mathrm{C}_{\text {substrate }} \mathrm{d}\right)^{-1}$

$x(0)$

$$
\mathrm{g} \mathrm{m}^{-3}
$$

0.069

1.2

$.69(0.05 ; 1.3)$

3.7)

\section{$x(0)$}

$v_{\max } / K_{\mathrm{M}}$

$$
\mathrm{m}^{-3}\left(\mathrm{~g}^{13} \mathrm{C} \mathrm{d}\right)^{-1}
$$

0.39

0.35

552

$108^{\text {n }}$

$\mathrm{L} \mathrm{kg}^{-1}$

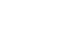

4.62

1.89

$0.51(0.10 ; 2.4)$

2.7)

sum

$$
\mathrm{g}^{13} \mathrm{C} \mathrm{m}^{-3}
$$

$0.67(0.12$

RMSE $^{9}$

a: estimated with MTB method; conversion factor 2,4-D $=0.822$ and ibuprofen $=1.41$ for conversion to $\mathrm{g}$ microbial biomass $\mathrm{dw}$ per $\mathrm{g}$ substrate; $\mathrm{b}$ : from slope of $\ln X$ at the end of the experiment; c: from slope of In $X$ in the initial growth phase; d: $K_{\mathrm{M}}$ of 2,4-D was calculated ${ }^{52}$; e: $K_{\mathrm{OC}}$ of 2,4-D (estimated $^{54}$ ) was used for rapid adsorption; f: $K_{\mathrm{oC}}$ of 2,4-DCP (estimated ${ }^{54}$ ) was used for slow adsorption (sequestration); $g$ 593 


\section{Figure legends:}

595 Figure 1. Measured and simulated ${ }^{13} \mathrm{C}$-label distribution. A) Top: ${ }^{13} \mathrm{C}_{6}-2,4-\mathrm{D}$, and B) bottom: ${ }^{13} \mathrm{C}_{6}$ 596 ibuprofen. Symbols show measured data, curves show the simulated turnover. Symbols: $\mathrm{CO}_{2}($ black 597 square), NER (grey circle), extractable ${ }^{13} \mathrm{C}$-label (dark grey triangle), and added compound, i.e., ibuprofen 598 or 2,4-D (black circle). Curves: Sequestered (black dashed (--)), extractable compound (dark grey $\left({ }^{-}\right)$), $599 \mathrm{CO}_{2}$ (black (-)), and living biomass + dead biomass + sequestered compound (=NER) (light grey). Error 600 bars show the standard deviation of the measurements as reported by Girardi et al. ${ }^{29}$ and Nowak et 601 al. ${ }^{27,28}$.

602

603

604

Figure 2. Simulations results for the growth of biomass. A) Top: ${ }^{13} \mathrm{C}_{6}-2,4-\mathrm{D}$ and B) bottom: ${ }^{13} \mathrm{C}_{6}$-ibuprofen. 605 Symbols show measured data, curves show simulation of the formation of living and dead biomass.

606 Symbols: Phospholipid fatty acids (PLFA; black circles), total amino acids (tAA; dark grey squares), and 607 total amino acids multiplied with a factor of two to yield total dead and alive biomass (empty squares).

608 Curves: Concentration of living biomass $X$ (black), concentration of dead biomass $X_{\text {dead }}$ (light grey), and 609 concentration of living and dead biomass $X+X_{\text {dead }}$ (dark grey). Error bars show the standard deviation of 610 the measurements as reported by Nowak et al. ${ }^{27,28}$.The dotted vertical line is the halftime of decay (In 2 / 611 b) after maximum measured PLFA and indicates were $>50 \%$ of tAA is necromass. 


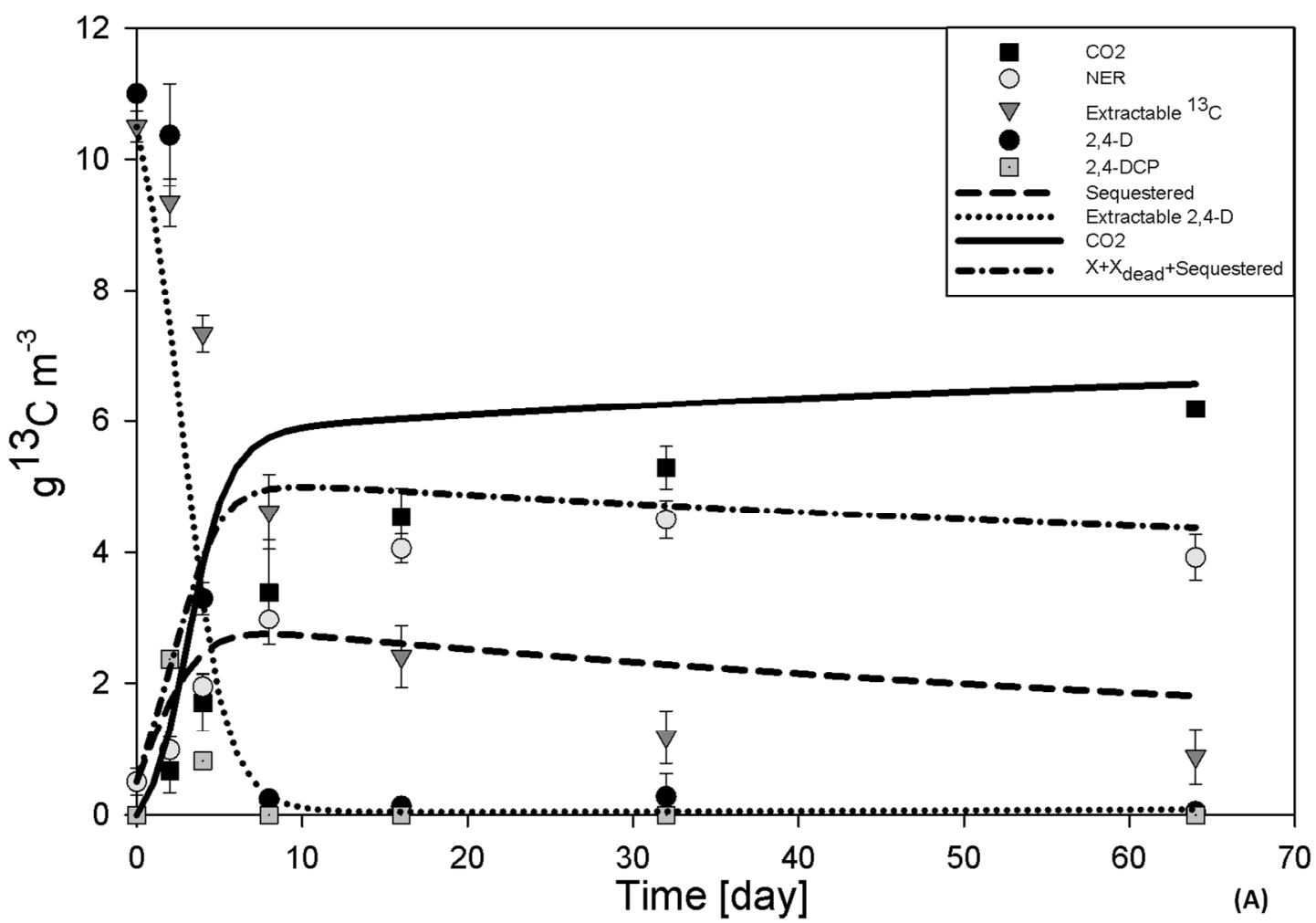

612

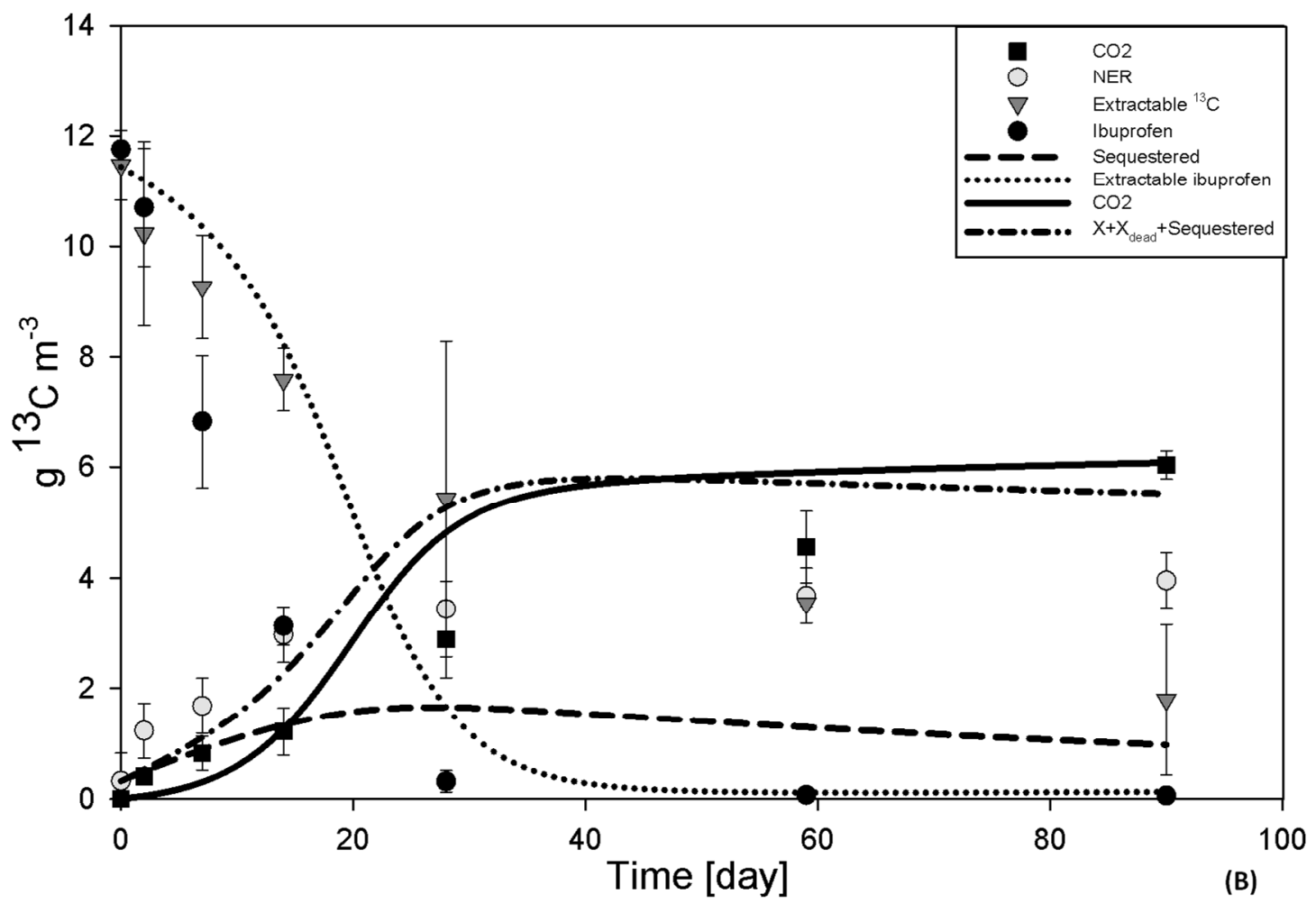

Figure 1 


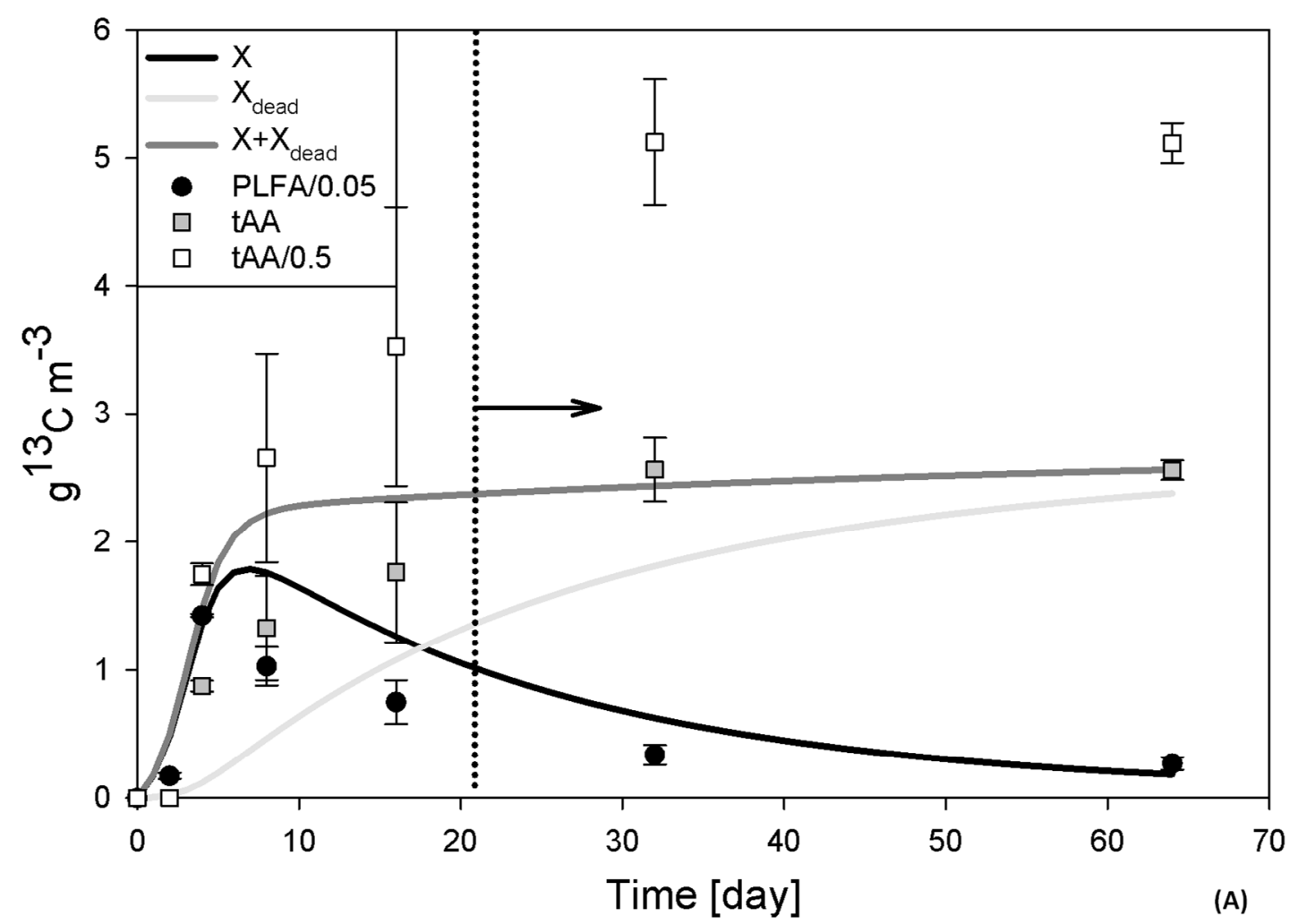

616

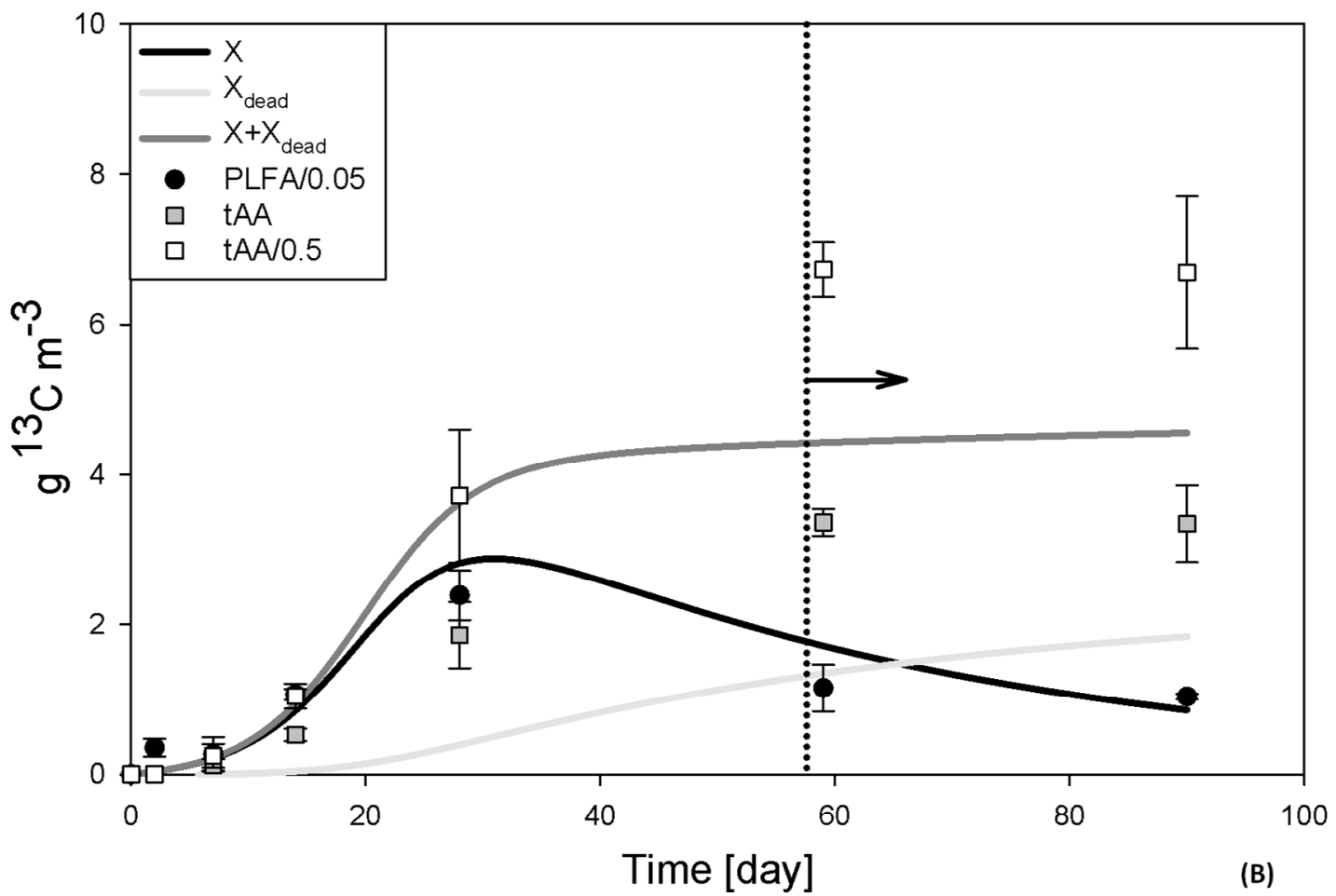

Figure 2 